\title{
The oestrogenic effects of gestodene, a potent contraceptive progestin, are mediated by its A-ring reduced metabolites
}

\author{
A E Lemus ${ }^{1,2}$, V Zaga ${ }^{2}$, R Santillán², G A García ${ }^{3}$, I Grillasca ${ }^{3}$, \\ P Damián-Matsumura ${ }^{1}, \mathrm{~K} \mathrm{~J} \mathrm{Jackson}^{4}$, A J Cooney ${ }^{4}, \mathrm{~F}_{\text {Larrea }}{ }^{2}$ and \\ G Pérez-Palacios ${ }^{5}$ \\ ${ }^{1}$ Department of Reproductive Biology, Universidad Autónoma Metropolitana-Iztapalapa, Mexico City, Mexico \\ ${ }^{2}$ Department of Reproductive Biology, Instituto Nacional de la Nutrición S. Zubirán, Mexico City, Mexico \\ ${ }^{3}$ Facultad de Química, Universidad Nacional Autónoma de México, Mexico City, Mexico \\ ${ }^{4}$ Department of Cell Biology, Baylor College of Medicine, Houston, Texas, USA \\ ${ }^{5}$ Dirección General de Salud Reproductiva, Secretaría de Salud, Mexico City, Mexico \\ (Requests for offprints should be addressed to A E Lemus, Departamento de Biología de la Reproducción, Instituto Nacional de la Nutrición S. Zubirán, \\ Vasco de Quiroga 15, México, D.F., C.P. 14000, Mexico; Email: ppal@cenids.ssa.gob.mx)
}

\begin{abstract}
Gestodene (17 $\alpha$-ethynyl-13 $\beta$-ethyl-17 $\beta$-hydroxy-4,15gonadien-3-one) is the most potent synthetic progestin currently available and it is widely used as a fertility regulating agent in a number of contraceptive formulations because of its high effectiveness, safety and acceptability. The observation that contraceptive synthetic progestins exert hormone-like effects other than their progestational activities, prompted us to investigate whether gestodene (GSD) administration may induce oestrogenic effects, even though the GSD molecule does not interact with intracellular oestrogen receptors (ER).

To assess whether GSD may exert oestrogenic effects through some of its neutral metabolites, a series of experimental studies were undertaken using GSD and three of its A-ring reduced metabolites. Receptor binding studies by displacement analysis confirmed that indeed GSD does not bind to the ER, whereas its $3 \beta, 5 \alpha$-tetrahydro reduced derivative $(3 \beta G S D)$ interacts with a relative high affinity with the ER. The $3 \alpha, 5 \alpha$ GSD isomer ( $3 \alpha \mathrm{GSD})$ also binds to the ER, though to a lesser extent. The ability of the A-ring reduced GSD derivatives to induce oestrogenic actions was evaluated by the use of two different molecular bioassays: (a) transactivation of a yeast system cotransfected with the human ER $\alpha(h E R \alpha)$ gene and oestrogen responsive elements fused to the $\beta$-galactosidase reporter vector and (b) transactivation of the hER $\alpha$ mediated transcription of the chloramphenicol acetyl transferase (CAT) reporter gene in a HeLa cells expression system. The oestrogenic potency of $3 \beta G S D$ was also
\end{abstract}

assessed by its capability to induce oestrogen-dependent progestin receptors (PR) in the anterior pituitary of castrated female rats.

The results demonstrated that $3 \beta$ GSD and $3 \alpha$ GSD were able to activate, in a dose-dependent manner, the hER $\alpha$ mediated transcription of both the $\beta$-galactosidase and the CAT reporter genes in the yeast and HeLa cells expression systems respectively. In both assays the $3 \beta$ derivative of GSD exhibited a significantly greater oestrogenic effect than its $3 \alpha$ isomer, while unchanged GSD and $5 \alpha$ GSD were completely ineffective. Neither $3 \beta G S D$ nor $3 \alpha$ GSD exhibited oestrogen synergistic actions. Interestingly, the pure steroidal anti-oestrogen ICI-182,780 diminished the transactivation induced by $3 \beta G S D$ and $3 \alpha$ GSD in the yeast expression system. Furthermore, administration of $3 \beta G S D$ resulted in a significant increase of oestrogendependent $\mathrm{PR}$ in the anterior pituitaries of castrated rats in comparison with vehicle-treated animals. The characteristics of the $3 \beta G S D$-induced PR were identical to those induced by oestradiol benzoate.

The overall results demonstrate that $3 \beta$ GSD and its $3 \alpha$ isomeric alcohol specifically bind to the ER and possess a weak intrinsic oestrogenic activity, whereas unmodified GSD does not. The data contribute to a better understanding of the GSD mechanism of action and allow the hypothesis to be advanced that the slight oestrogenlike effects attributable to GSD are mediated by its non-phenolic, tetrahydro reduced metabolites.

Journal of Endocrinology (2000) 165, 693-702

\section{Introduction}

The availability of novel, very potent synthetic progestins has allowed the development of the so-called third generation contraceptive formulations, representing a breakthrough in the field of fertility regulation (Kuhl 1996). The most effective of these progestins is gestodene (GSD), a synthetic 19-nor steroid that has been widely 
used in low dose combined oral contraceptives (Fotherby \& Caldwell 1994, Wilde \& Balfour 1995). Recently, a series of studies (WHO 1995a,b, Jick et al. 1995, Lewis et al. 1996) have suggested that low dose, combined oral contraceptives pills, containing highly potent progestins, such as GSD, probably carry a small risk of venous thromboembolic disease (VTD) beyond that attributable to combined oral formulations containing less potent progestins such as norethisterone or levonorgestrel. The origin of VTD associated with the use of hormonal contraceptives is multifactorial and a number of mechanisms has been involved (Inman \& Vessey 1968, Vessey et al. 1986, Helmrich et al. 1987, WHO 1989, Vandenbroucke et al. 1994, WHO 1995b, Spitzer et al. 1996, Winkler 1998). The unexpected association between the use of GSD containing oral contraceptives and an increased risk of VTD raised the controversial question as to whether GSD may exert potent oestrogen agonistic or synergistic effects (WHO Scientific Group 1998), particularly since the GSD molecule does not interact with intracellular oestrogen receptors (ER) (Düstenberg et al. 1987).

Evidence has been accumulated over the last years indicating that contraceptive synthetic progestins exert potent hormone-like effects other than their progestational activities (Vilchis et al. 1986, Pérez-Palacios et al. 1992, Lemus et al. 1997). The hormonal agonist, synergistic and even antagonistic effects of synthetic progestins are mediated either by their interaction with the wrong receptors (Bardin 1983, Chávez et al. 1985, Lemus et al. 1992) or by their metabolic conversion products (Larrea et al. 1987, Lemus et al. 1992).

This study was aimed at elucidating the role of the GSD metabolites in determining oestrogen-like effects. A series of experiments were undertaken to assess whether non-phenolic A-ring reduced derivatives of GSD may be involved in mediating its oestrogenic activity, taking advantage of the fact that GSD, after its administration, undergoes extensive metabolism in a similar manner to other 19-nor synthetic progestins (Düstenberg et al. 1987). The in vivo formation of $3 \beta, 5 \alpha$

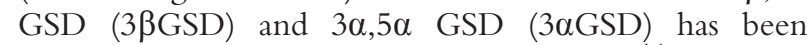
demonstrated after the administration of ${ }^{14} \mathrm{C}$-labelled GSD to normal women (Düstenberg et al. 1987). Assessment of the intrinsic oestrogenic potency of GSD and its derivatives was done by the use of ER binding studies, oestrogen-induced transactivation systems in yeast and HeLa cells previously co-transfected with human ER $\alpha(h E R \alpha)$ expression vectors and their cognate reporter vectors, and induction of oestrogendependent progestin receptors (PR) in the rat anterior pituitary.

Additional interest in conducting these studies derived from the observation in our laboratory (Vilchis et al. 1986, Moralí et al. 1990, Pérez-Palacios et al. 1992) that norethisterone, a synthetic contraceptive progestin, exerts potent oestrogen-like effects through its neutral tetrahydro reduced metabolites.

\section{Materials and Methods}

\section{Steroids and chemicals}

Authentic GSD was kindly provided by Schering AG (Berlin, Germany) and $5 \alpha$-dihydro GSD ( $5 \alpha \mathrm{GSD}$ ) was synthesised by lithium-ammonia reduction of GSD, crystallised from ethyl acetate-hexane and purified by flash chromatography (Still et al. 1978). A 60\% yield of the pure compound was obtained. The $3 \alpha, 5 \alpha \mathrm{GSD}$ tetrahydro derivative $(3 \alpha \mathrm{GSD})$ was prepared from reduction of $5 \alpha$ GSD with L-selectride under anhydrous conditions (Brown \& Krifhnamurthy 1972). Sodium hydroxide and hydrogen peroxide were added, and following extraction with ethyl acetate, a mixture of $3 \alpha-(98 \%)$ and $3 \beta-(2 \%)$ GSD derivatives were obtained (yield: $95 \%$ ). Synthesis of $3 \beta, 5 \alpha$ tetrahydro GSD ( $3 \beta G S D)$ was performed by sodium borohydride reduction (Bowers et al. 1958) of 5aGSD (yield: $70 \%$ ). The molecular structures of GSD and its metabolites are depicted in Fig. 1. Chemical purity of GSD and its derivatives was assessed by their melting points, HPLC behaviour, infrared absorption, and ${ }^{13} \mathrm{C}$ - and ${ }^{1} \mathrm{H}$-nuclear magnetic resonance. The physical and spectroscopic constants of the A-ring reduced GSD derivatives were as follows:

$5 \alpha$ GSD: m.p. $168-170{ }^{\circ} \mathrm{C}$; i.r. (KBr) $3362,3258,3047$, 2948, 2924, 2857, 2086, $1697 \mathrm{~cm}^{-1}$; ${ }^{1} \mathrm{H}-\mathrm{NMR}$ (300 $\left.\mathrm{MHz}, \mathrm{CDCl}_{3}\right) \delta 5.92(\mathrm{dd}, J=5.7$ and $1.5 \mathrm{~Hz}, 1 \mathrm{H}), 5 \cdot 67$ (dd, $J=5.7$ and $3 \cdot 6 \mathrm{~Hz}, 1 \mathrm{H}), 2 \cdot 60(\mathrm{~S}, 1 \mathrm{H}), 0 \cdot 867(\mathrm{t}, J=7 \cdot 5$ $\mathrm{Hz}, 3 \mathrm{H}) ;{ }^{13} \mathrm{C}-\mathrm{NMR}\left(75 \mathrm{MHz}, \mathrm{CDCl}_{3}\right) \delta 11 \cdot 11,20 \cdot 36$, $25 \cdot 60,29 \cdot 51,30 \cdot 30,30 \cdot 37,33 \cdot 70,38 \cdot 74,41 \cdot 21,43 \cdot 67$, $45 \cdot 59,47 \cdot 91,48 \cdot 53,55 \cdot 80,56 \cdot 50,74 \cdot 89,83 \cdot 06,83 \cdot 82$, 132.01, 135.56, 211.51; MS (FAB) 313.

3aGSD: m.p. $178-181{ }^{\circ} \mathrm{C}$; i.r. (KBr) $3567,3392,3252$, 3051, 2929, $2089 \mathrm{~cm}^{-1} ;{ }^{1} \mathrm{H}-\mathrm{NMR}$ (300 MHz, $\left.\mathrm{CDCl}_{3}\right) \delta$ $5.93(\mathrm{dd}, J=5.7$ and $1.52 \mathrm{~Hz}, 1 \mathrm{H}), 5.65(\mathrm{dd}, J=5.7$ and $3.6 \mathrm{~Hz}, 1 \mathrm{H}), 4.09(\mathrm{~m}, 1 \mathrm{H}), 2.60(\mathrm{~s}, 1 \mathrm{H}), 0.85$ (t, $J=7.5$ $\mathrm{Hz}, 3 \mathrm{H}) ;{ }^{13} \mathrm{C}-\mathrm{NMR}\left(75 \mathrm{MHz}, \mathrm{CDCl}_{3}\right) \delta 11 \cdot 10,20 \cdot 38$, $23 \cdot 56,25 \cdot 18,29 \cdot 60,30 \cdot 74,32 \cdot 90,33 \cdot 45,36 \cdot 15,39 \cdot 05$, $40 \cdot 54,46 \cdot 96,48 \cdot 33,55 \cdot 87,56 \cdot 81,66 \cdot 33,74 \cdot 68,83 \cdot 31$, 83.83, 132.30, 135.33; MS (FAB) 315.

3ßGSD: m.p. $139-141{ }^{\circ} \mathrm{C}$; i. r. (KBr) 3373, 3281, 2919, $2859 \mathrm{~cm}^{-1} ;{ }^{1} \mathrm{H}-\mathrm{NMR}\left(300 \mathrm{MHz}, \mathrm{CDCl}_{3}\right) \delta 5 \cdot 84$ $(\mathrm{dd}, J=5 \cdot 5$ and $1 \cdot 2 \mathrm{~Hz}, 1 \mathrm{H}), 5 \cdot 57(\mathrm{dd}, J=5 \cdot 5$ and $3.6 \mathrm{~Hz}$, $1 \mathrm{H}), 3.47(\mathrm{~m}, 1 \mathrm{H}), 2.53(\mathrm{~s}, 1 \mathrm{H}), 0 \cdot 768(\mathrm{t}, J=7 \cdot 2 \mathrm{~Hz}, 3 \mathrm{H})$; ${ }^{13} \mathrm{C}-\mathrm{NMR}\left(75 \mathrm{MHz}, \mathrm{CDCl}_{3}\right) \delta 10 \cdot 83,20 \cdot 21,25 \cdot 37$, $28 \cdot 12,29 \cdot 42,30 \cdot 60,33 \cdot 22,35 \cdot 27,38 \cdot 86,41 \cdot 17,42 \cdot 86$, $45 \cdot 95,48 \cdot 11,55 \cdot 68,56 \cdot 60,70 \cdot 05,74 \cdot 18,83 \cdot 32,131 \cdot 99$, 135·25; MS (FAB) 315.

$\left[2,4,6,7-{ }^{3} \mathrm{H}\right]$ oestradiol $\left(\left[{ }^{3} \mathrm{H}\right] \mathrm{E}_{2}\right)$, specific activity (sp. act.) $97 \mathrm{Ci} / \mathrm{mmol}$ was purchased from Amersham 


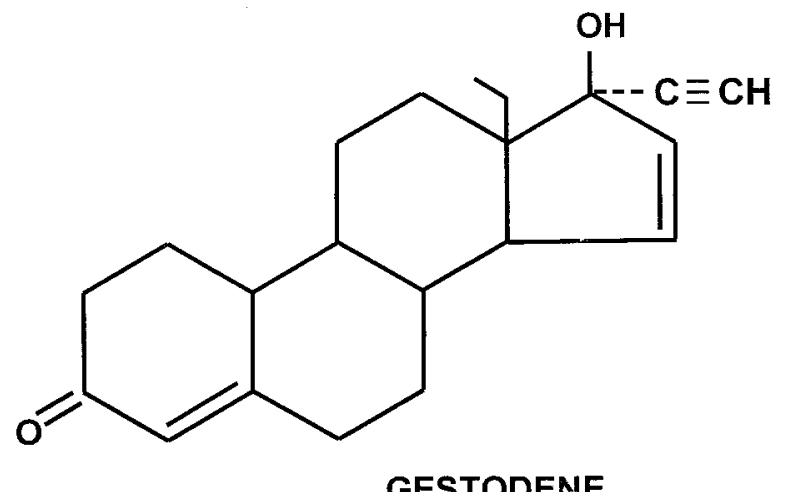

GESTODENE

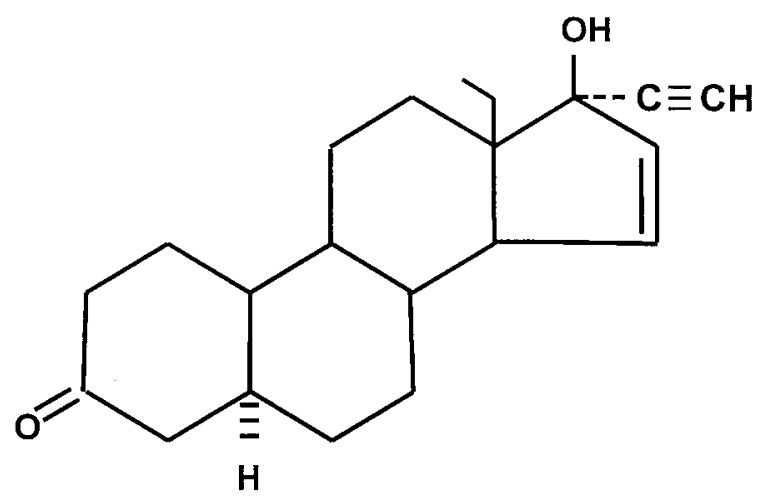

$5 \propto$ DIHYDROGESTODENE

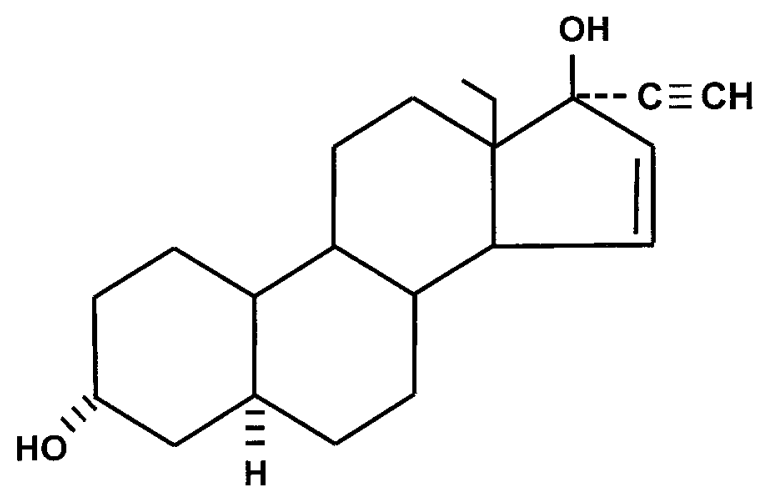

$3 \alpha, 5 \alpha$ TETRAHYDROGESTODENE

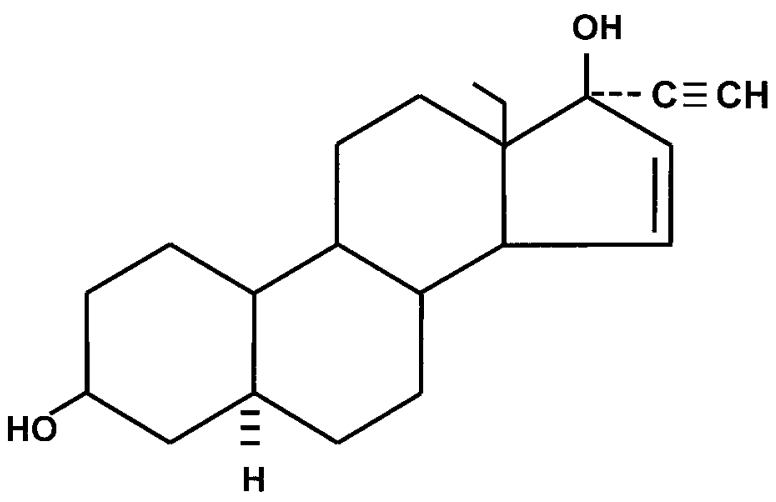

3ß,5 $\alpha$ TETRAHYDROGESTODENE

Figure 1 Molecular structures of GSD and three of its A-ring reduced metabolites, $5 \alpha$-dihydrogestodene (5 $\alpha$ GSD), $3 \alpha, 5 \alpha$-tetrahydrogestodene ( $3 \alpha, 5 \alpha \mathrm{GSD})$ and $3 \beta, 5 \alpha$-tetrahydrogestodene $(3 \beta, 5 \alpha \mathrm{GSD})$.

International plc (Bucks, UK) and its radiochemical purity was established by its thin-layer chromatographic behaviour and by repeated crystallisation of an aliquot to constant specific activity. Other natural and synthetic steroids were supplied by Sigma Chemical Co. (St Louis, MO, USA). The anti-oestrogen ICI-182,780 was obtained from Zeneca Farma (Mexico City, Mexico). All reagents and solvents used were analytical grade.

\section{Oestradiol receptor binding studies}

All procedures were performed in accordance with the Guidelines on the Handling and Training of Laboratory Animals published by the Universities Federation for Animal Welfare and approved by the Research Ethics Board of the Universidad Autonoma Metropolitana. Immature female, intact Wistar rats (body weight: 100$200 \mathrm{~g}$ ) without oestrogen priming were used for these studies. Animals were kept under a $14 \mathrm{~h}$ light: $10 \mathrm{~h}$ darkness cycle, maintained on food and water and allowed to feed ad libitum. Animals were killed by decapitation and uteri were immediately removed, blotted and weighed; thereafter all procedures were carried out at $4{ }^{\circ} \mathrm{C}$. Uterine tissues were homogenised in chilled TEDLM buffer (20 mM Tris- $\mathrm{HCl}, \mathrm{pH} 7.4$ at $4{ }^{\circ} \mathrm{C}, 1.5 \mathrm{mM}$ EDTA, $0.25 \mathrm{mM}$ dithiotreitol, $10 \mu \mathrm{g} / \mathrm{ml}$ leupeptine, and $10 \mathrm{mM}$ sodium molibdate) in a ratio $(\mathrm{w} / \mathrm{v}) 1: 6$, with three $10 \mathrm{~s}$ bursts.

The homogenate was centrifuged at $180000 \boldsymbol{g}$ for $1 \mathrm{~h}$ at $2{ }^{\circ} \mathrm{C}$ in an SW $50 \cdot 1$ rotor (Beckman Instruments, Palo Alto, CA, USA). Cytosol protein was determined by the Bradford's dye binding method (Bradford 1976) using bovine serum albumin as a standard.

Stereospecificity of the binding of GSD and its derivatives to ER was assessed by displacement analysis as previously reported (Chávez et al. 1985). Uterine cytosol aliquots $(2 \cdot 0-3 \cdot 4 \mathrm{mg}$ protein $/ \mathrm{ml})$ were incubated with $\left[{ }^{3} \mathrm{H}\right] \mathrm{E}_{2}$ in the absence or presence of increasing concentrations $(1-500 \mathrm{nM})$ of radioinert $\mathrm{E}_{2}$ at $2-4{ }^{\circ} \mathrm{C}$ for 18-20 h. The relative binding affinities (RBA) of GSD 
and its derivatives to cytosol ERs were evaluated by their capability to displace bound $\left[{ }^{3} \mathrm{H}\right] \mathrm{E}_{2}$ from the ER. Radioactive content in the samples was determined in a Packard Tri-Carb liquid scintillation spectrometer, Model 1900 TR (Packard, Downers Grove, IL, USA) using Insta-Gel Plus as counting solution. The counting efficiency for ${ }^{3} \mathrm{H}$ was $65 \%$ and quenching was corrected in all samples by external standardisation. The RBA and the inhibition constant $\left(K_{\mathrm{i}}\right)$ of GSD and its metabolites were calculated according to procedures previously described (Cheng \& Prusoff 1973, Reel et al. 1979).

\section{Oestrogen-induced yeast transactivation system}

Oestrogen-like activity of GSD and its A-ring reduced derivatives was assessed in the yeast expression system as previously reported (Lyttle et al. 1992), where Saccharomyces cerevisiae hyperpermeable yeast strain RS $188 \mathrm{~N}$ was co-transfected with an expression vector containing the hER $\alpha$, under the control of a yeast copper metallothionein promoter and a $\beta$-galactosidase reporter vector, expression of which was under the control of oestrogen response elements (EREs). Yeast cultures were grown overnight, as described by Sherman et al. (1982), diluted to an optical density (o.d.) of 0.5 at $660 \mathrm{~nm}$ and allowed to grow for $1 \mathrm{~h}$, after which ER $\alpha$ synthesis was induced with $100 \mu \mathrm{M}$ copper sulphate for an additional hour and incubated for $4.5 \mathrm{~h}$ with varying concentrations of GSD, its derivatives, and/or other naturally occurring and synthetic steroids including the pure anti-oestrogen ICI-182,780. Oestradiol served as the positive control, while dihydrotestosterone (DHT), progesterone $\left(\mathrm{P}_{4}\right)$ and pregnenolone $\left(\mathrm{P}_{5}\right)$ were the negative controls. Yeast were harvested by centrifugation, washed with $\mathrm{Z}$ buffer $\left(50 \mathrm{mM} \mathrm{NaH} \mathrm{PO}_{4}, \mathrm{pH} \quad 7 \cdot 0\right.$, $10 \mathrm{mM} \mathrm{KCl}, 1 \mathrm{mM} \mathrm{MgSO}$, $5 \mathrm{mM} \beta$-mercaptoethanol) and the cytosolic fraction was obtained by vortexing with glass beads in $\mathrm{Z}$ buffer followed by centrifugation at $10000 \mathrm{~g}$. The supernatant was assayed for $\beta$-galactosidase activity using $o$-nitrophenyl- $\beta$-d-galactoside $(4 \mathrm{mg} / \mathrm{ml})$ as substrate, and the o.d. at $420 \mathrm{~nm}$ was registered after $10 \mathrm{~min}$.

\section{Oestrogen-induced HeLa cells transactivation system}

The oestrogen-like actions of GSD and its A-ring reduced derivatives were also assessed in the $\mathrm{HeLa}$ cells cotransfected with the mammalian expression vector for human ER $\alpha$ (PCR 3-2-hER $\alpha$ ) and its cognate reporter vector EREe1b-chloramphenicol acetyl transferase (CAT) (Cooney et al. 1992, 1993). HeLa cells were plated the day before transfection in a six-well plate at a density of $3 \cdot 0 \times 10^{5}$ cells/well in DMEM-high glucose (HG) without phenol red, which was supplemented with $5 \%$ stripped fetal bovine serum (FBS) and $10000 \mathrm{U}$ of penicillin and streptomycin. Cells were maintained in $5 \% \mathrm{CO}_{2}$ atmosphere at $37^{\circ} \mathrm{C}$. The next day, cells were visualised to assure cell density between 30 and 50\%.
Transfections were performed in triplicate using SuperFect (Qiagen, Inc., Valencia, CA, USA). In a sterile tube, $100 \mu \mathrm{l}$ of serum-free media was aliquoted and the DNA was added, after vortexing $10 \mu \mathrm{l}$ of SuperFect reagent were added and vortexed for $10 \mathrm{~s}$. The samples were incubated at room temperature for 5-10 $\mathrm{min}$ and afterwards $600 \mu \mathrm{l}$ of supplemented DMEM-HG were added to each sample and the mixture was pipetted up and down twice. The medium containing the transfection complexes was added to the cell monolayer previously rinsed with PBS. The plates were incubated for $3 \mathrm{~h}$ at $37^{\circ} \mathrm{C}$ with $5 \% \mathrm{CO}_{2}$. After incubation, the plates containing the transfection complexes were rinsed with PBS, and $3 \mathrm{ml}$ of complete growth medium were added to each well. Twenty-four hours later, the medium in each well was replaced with complete medium containing different concentrations of GSD, $5 \alpha \mathrm{GSD}, 3 \alpha \mathrm{GSD}, 3 \beta \mathrm{GSD}$ and $\mathrm{E}_{2}$. Dimethyl sulphoxide (DMSO) or ethanol (EtOH) were used as steroid vehicles. The next day the plates were harvested for CAT assays as previously described (Cooney et al. 1992, 1993). Briefly, the medium was aspirated from each well and the plates were rinsed with PBS, and $1 \mathrm{ml}$ of cold TEN (40 mM Tris-HCl, pH 8.0, 1 mM EDTA, $150 \mathrm{mM} \mathrm{NaCl}$ ) buffer was added to each well. The cells were removed from the monolayer with a cell lifter, and the contents of each well were transferred to an $1.5 \mathrm{ml}$ tube. The tubes were centrifuged for $5 \mathrm{~min}$ at $4{ }^{\circ} \mathrm{C}$. The supernatant was removed and $80 \mu \mathrm{l}$ of cold $0.25 \mathrm{M}$ Tris$\mathrm{HCl}, \mathrm{pH} 8.0$ were added to each sample which was kept on ice. Samples went through three freeze-thaw cycles and centrifugation at $4{ }^{\circ} \mathrm{C}$. The liquid CAT assay as described by Seed \& Sheen (1998) was used to determine the CAT activity, employing $5 \mu \mathrm{g}$ protein, $25 \mu \mathrm{g}$ of butyryl coenzyme-A (Sigma Chemical Co., St Louis, MO, USA), $2 \times 10^{5}$ c.p.m. of xylene-extracted $\left[{ }^{3} \mathrm{H}\right]$ chloramphenicol (Dupont NEN Research Products, Boston, MA, USA) and $0.25 \mathrm{M}$ Tris $-\mathrm{HCl}, \mathrm{pH} 8.0$ for $1 \mathrm{~h}$ incubation at $37^{\circ} \mathrm{C}$.

\section{Oestrogen-induced rat anterior pituitary $P R$}

The induction of PR in the anterior pituitary (AP) of castrated rats was used as previously described (Vilchis et al. 1986) to further assess the oestrogenic potency of the $3 \beta$ GSD derivative. Adult female Wistar rats (body weight 200-250 g) were ovariectomised under ether anaesthesia and kept under a $14 \mathrm{~h}$ light : $10 \mathrm{~h}$ darkness cycle with free access to water and food. Three weeks after ovariectomy, groups of 20 rats each were daily injected for 6 consecutive days with $100 \mu \mathrm{l}$ of propyleneglycol containing either 500 , 1000 or $1500 \mu \mathrm{g}$ of $3 \beta \mathrm{GSD}$. Animals treated with $5 \mu \mathrm{g} /$ day for 6 days oestradiol benzoate $\left(E_{2} B\right)$ or with vehicle alone were used as experimental controls. After completion of the treatment, animals were killed by decapitation and the AP were immediately removed, rinsed with ice-cold TEDM buffer $(20 \mathrm{mM}$ Tris- $\mathrm{HCl}, \mathrm{pH} 7 \cdot 4$ at 
$4{ }^{\circ} \mathrm{C}, \quad 1.5 \mathrm{mM}$ EDTA, $0.25 \mathrm{mM}$ dithiothreitol, and $10 \mathrm{mM}$ sodium molibdate), blotted and weighed. Thereafter all procedures were carried out at $4{ }^{\circ} \mathrm{C}$. Tissues were homogenised in a glass homogeniser with a Teflon pestle with TEDM buffer supplemented with $10 \%$ glycerol (v/v) and $10 \mu \mathrm{g} / \mathrm{ml}$ leupeptine in a tissue:buffer ratio of $1: 6$ $(\mathrm{w} / \mathrm{v})$. Pituitary cytosol preparations were obtained as described for binding studies. Aliquots of cytosol (300$400 \mu \mathrm{l} ; 10-14 \mathrm{mg}$ protein $/ \mathrm{ml}$ ) were incubated with $4 \mathrm{nM}$ $\left[6,7-{ }^{3} \mathrm{H}\right]$ ORG 2058 (promegestone) for $4 \mathrm{~h}$ at $4{ }^{\circ} \mathrm{C}$ and layered on the top of linear sucrose gradients $(20-35 \%$ in TEDM buffer supplemented with $10 \%$ (v/v) glycerol). An excess $(125 \times)$ of radioinert ORG 2058 was added to an incubation set of cytosols from animals treated with $3 \beta G S D$. BSA, on a parallel gradient, was used as an external marker. Gradients were centrifuged at $398000 \mathrm{~g}$ for $2 \mathrm{~h}$ and $30 \mathrm{~min}$ at $2{ }^{\circ} \mathrm{C}$ in a VTi 65 rotor (Beckman Instruments, Palo Alto, CA, USA). Fractions of $150 \mu \mathrm{l}$ each were collected from the bottom of the gradients and their radioactive content determined.

\section{Statistical analysis}

The results of transactivation studies in the yeast and HeLa cells expression systems are expressed as mean \pm S.D. for each experimental group. Significance of differences was evaluated by Student's $t$-test. Group differences were considered to be significant when $P \leq 0 \cdot 05$.

\section{Results}

\section{Competition of GSD and its metabolites for ER}

The effects of increasing concentrations of non-radioactive GSD and its A-ring reduced derivatives upon the $\left[{ }^{3} \mathrm{H}\right] \mathrm{E}_{2}$ binding to uterine cytosolic ER obtained from immature rats are shown in Fig. 2. The RBAs and the inhibition constant $\left(K_{\mathrm{i}}\right)$ for each steroid are shown in Table 1 . The only striking competitor for the ER binding sites was the $3 \beta$ GSD derivative (RBA: $1 \cdot 34 \%$; $K_{\mathrm{i}}: 40 \mathrm{nM}$ ), though the $3 \alpha \mathrm{GSD}$ isomer also induced a slight competitive effect (RBA: $0 \cdot 67 \% ; K_{\mathrm{i}}: 80 \mathrm{nM}$ ). Unmodified GSD and $5 \alpha \mathrm{GSD}$ were completely ineffective. Naturally occurring $\mathrm{E}_{2}$ used as positive control was the most potent inhibitor.

Transactivation of the yeast expression system by GSD metabolites

The oestrogen-like effects of GSD and its A-ring reduced metabolites, as assessed in the hyperpermeable yeast expression system, are shown in Fig. 3. The $3 \beta, 5 \alpha$ tetrahydro derivative of GSD and its $3 \alpha, 5 \alpha$ isomer were able to induce the ER $\alpha$-dependent transactivation of the yeast system in a dose-response manner, similar to that induced by naturally occurring $\mathrm{E}_{2}$, yet to a significantly

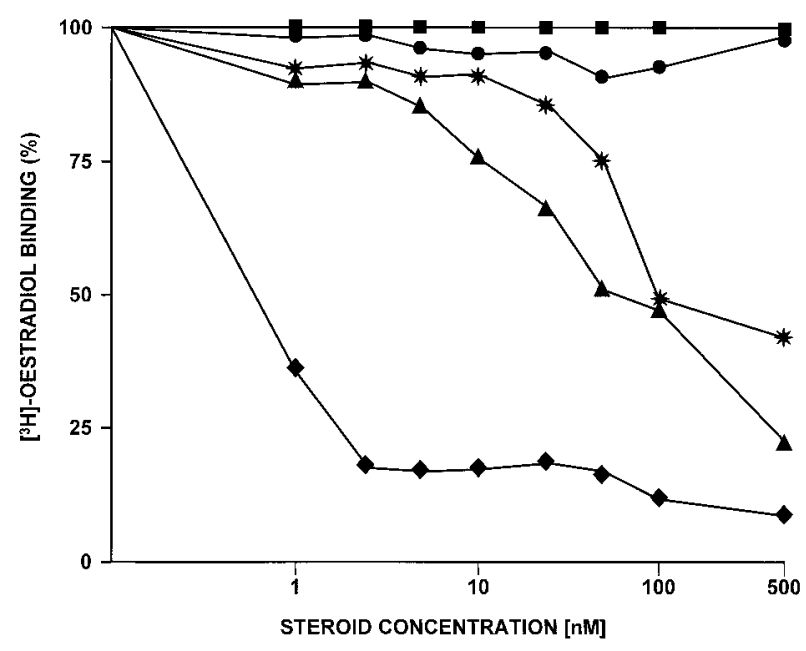

Figure 2 Competition of GSD and three A-ring reduced GSD metabolites for the rat uterine $\left[{ }^{3} \mathrm{H}\right]$-ER binding sites. Oestradiol receptors were labelled in vitro by overnight incubations of uterine cytosol preparations from prepubertal animals, with $1 \mathrm{nM}\left[{ }^{3} \mathrm{H}\right] \mathrm{E}_{2}$, at $4{ }^{\circ} \mathrm{C}$ (final incubation volume $=200 \mu \mathrm{l}$ ). Increasing concentrations of the following radioinert steroids were added to the incubations: $\mathrm{E}_{2}(\bullet), \operatorname{GSD}(\boldsymbol{\square}), 5 \alpha \mathrm{GSD}(\bullet), 3 \alpha \mathrm{GSD}(*)$ and $3 \beta G S D(\boldsymbol{\Delta})$. Bound and free fractions were separated by the addition of a dextran-coated charcoal suspension. Each point represents the mean of five experiments in triplicate. The results show that $3 \beta G S D$ was the most effective synthetic steroid competitor for ER binding sites, though $3 \alpha \mathrm{GSD}$ also induced a slight competitive effect. Unmodified GSD and 5 $\alpha$ GSD were completely ineffective. Naturally occurring $E_{2}$, used as positive control, was the most potent competitor.

lesser extent. At steroid concentrations that induced the highest $\beta$-galactosidase transactivation (Fig. 3), the oestrogen-like effect of $3 \beta G S D(50 \mathrm{nM})$ was 100 -fold less potent than $\mathrm{E}_{2}(0.5 \mathrm{nM})$, whereas $3 \alpha \mathrm{GSD}(500 \mathrm{nM})$ was 25 -fold less potent than $3 \beta$ GSD $(20 \mathrm{nM})$. The $5 \alpha$ dihydro derivative of GSD had very little, if any, effect on the oestrogen-mediated transactivation of the yeast expression system, even at $1000 \mathrm{nM}$ dose, whereas unmodified GSD was completely devoid of oestrogen-like effects as depicted in Fig. 3. A lack of oestrogenic potency of DHT, $\mathrm{P}_{4}$ and $\mathrm{P}_{5}$, used as negative controls, was observed on this expression system. When $1 \mu \mathrm{M}$ of the pure anti-oestrogen

Table 1 Relative binding affinities (RBAs) and inhibition constants $\left(K_{\mathrm{i}}\right)$ of natural and synthetic steroids for cytosol ERs. $\left[{ }^{3} \mathrm{H}\right] \mathrm{E}_{2}$ was used as radioligand. RBAs were determined according to Reel et al. (1979) and $K_{\mathrm{i}}$ values were calculated according to Cheng \& Prusoff (1973)

\begin{tabular}{|c|c|c|}
\hline Steroid competitors & RBA (\%) & $\boldsymbol{K}_{\mathbf{i}}(\mathrm{nM})$ \\
\hline GSD & - & - \\
\hline $5 \alpha G S D$ & - & - \\
\hline $3 \alpha G S D$ & $0 \cdot 67$ & 80 \\
\hline $3 \beta G S D$ & $1 \cdot 34$ & 40 \\
\hline $\mathrm{E}_{2}$ & 100 & 0.53 \\
\hline
\end{tabular}




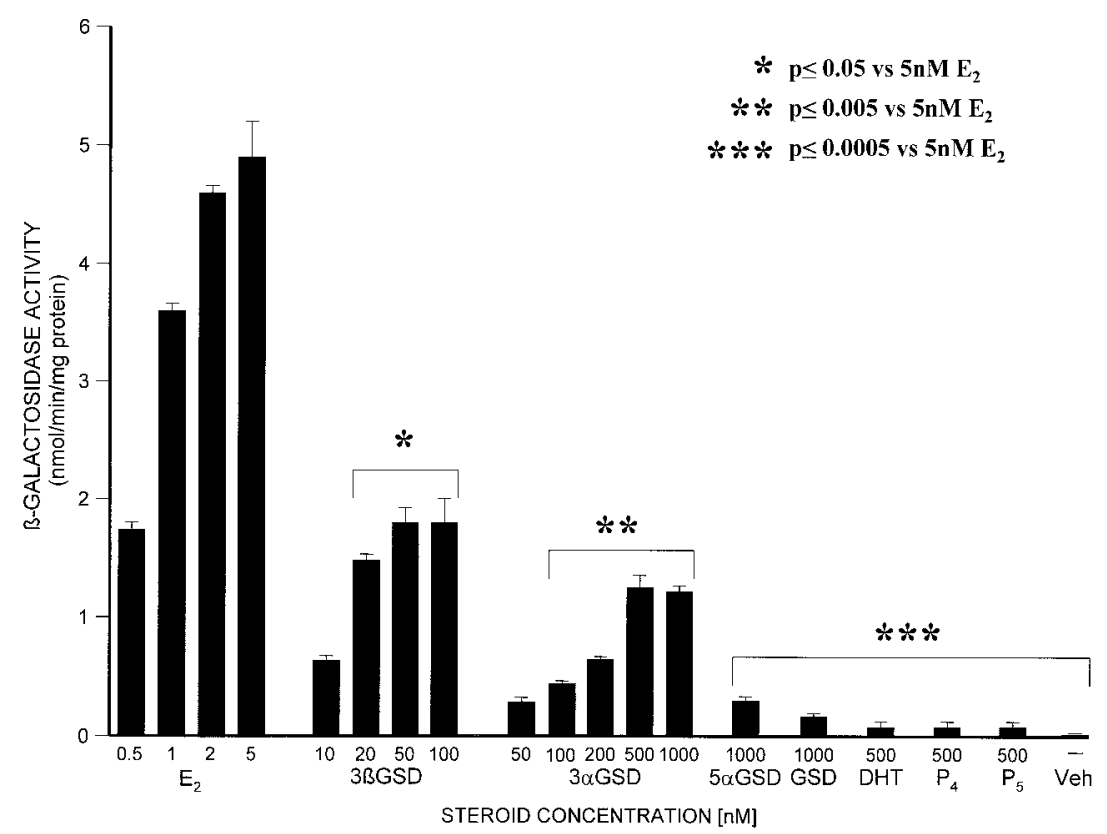

Figure 3 Activation of hER $\alpha$-mediated $\beta$-galactosidase activity by GSD and its A-ring reduced metabolites in a yeast expression system. The yeast strain RS $188 \mathrm{~N}$ was co-transfected with an expression vector containing the $\mathrm{hER} \alpha$ and oestrogen responsive elements fused to the $\beta$-galactosidase reporter vector. Yeast were grown in the presence of increasing concentrations of GSD and its derivatives, as well as naturally occurring steroids. The results are expressed as $\beta$-galactosidase activity. Each point represents the mean \pm S.D. of three experiments in triplicate (for details see the text). The results show that 3BGSD and $3 \alpha G S D$ induced the $h E R \alpha$-mediated $\beta$-galactosidase activity in a dose-dependent manner, similar to that observed with naturally occurring $E_{2}$ used as positive control. $5 \alpha G S D$ exhibited very little, if any, oestrogen-like effect, while unchanged GSD was completely ineffective. Dihydrotestosterone $(\mathrm{DHT})$, progesterone $\left(\mathrm{P}_{4}\right)$, pregnenolone $\left(\mathrm{P}_{5}\right)$ and the vehicle (Veh), used as negative controls, were also ineffective.

ICI-182,780 was added to the incubations of cotransfected yeast cultures with either $5 \mu \mathrm{M} \mathrm{E} \mathrm{E}_{2}, 100 \mu \mathrm{M}$ $3 \beta \mathrm{GSD}$ or $500 \mu \mathrm{M} 3 \alpha \mathrm{GSD}$, a significant diminution of the $\beta$-galactosidase activity induced by $\mathrm{E}_{2}$ and the two GSD tetrahydro metabolites was observed, as depicted in Fig. 4. To investigate whether GSD and its derivatives may exert synergistic oestrogenic effects, yeast cultures were incubated with $100 \mathrm{nM}$ GSD, $100 \mathrm{nM} 3 \beta \mathrm{GSD}$ and $500 \mathrm{nM}$ $3 \alpha$ GSD in the presence of $0.5 \mathrm{nM} \mathrm{E}_{2}$. The results (Fig. 5) showed that neither GSD nor its two tetrahydro-reduced derivatives exhibit synergistic effects with $E_{2}$ in this system. Oestradiol exerted additive effects with the GSD tetrahydro metabolites.

\section{Transactivation of the HeLa cells expression system by} GSD metabolites

The oestrogen-like effects of GSD and its derivatives as assessed in the HeLa cells expression system are shown in Fig. 6. In general, the results were similar, though not identical, to those obtained in the transactivation yeast expression system. The $3 \beta G S D$ derivative exhibited oestrogen agonistic effects, inducing transactivation of the hER $\alpha$-mediated CAT activity, while its $3 \alpha$ isomer also induced the transactivation of the CAT system to a significant lesser extent. Unmodified GSD was completely ineffective to activate the hER $\alpha$-mediated CAT activity, thus indicating a lack of oestrogen agonistic effect (Fig. 6).

\section{$3 \beta G S D$ induction of rat anterior pituitary $P R$}

Incubations of AP cytosol from vehicle-treated castrated rats with $\left[{ }^{3} \mathrm{H}\right] \mathrm{ORG} 2058$ exhibited very little, if any, progestin binding activity as disclosed by the employed gradient labelling technique (Fig. 7), whereas oestradiol benzoate $\left(E_{2} B\right)$ administration $(5 \mu \mathrm{g} /$ day) fully restored the pituitary content of oestrogen-dependent PR. Daily administration of $3 \beta G S D$ for 6 consecutive days to castrated animals successfully restored anterior pituitary $\mathrm{PR}$ in a dose-dependent manner; thus the dose of $500 \mu \mathrm{g} /$ day was almost ineffective, whereas the daily doses of 1000 and $1500 \mu \mathrm{g}$ were able to induce the presence of $\mathrm{PR}$ in the rat AP. The $\left[{ }^{3} \mathrm{H}\right] \mathrm{ORG} 2058$ complexes in the 


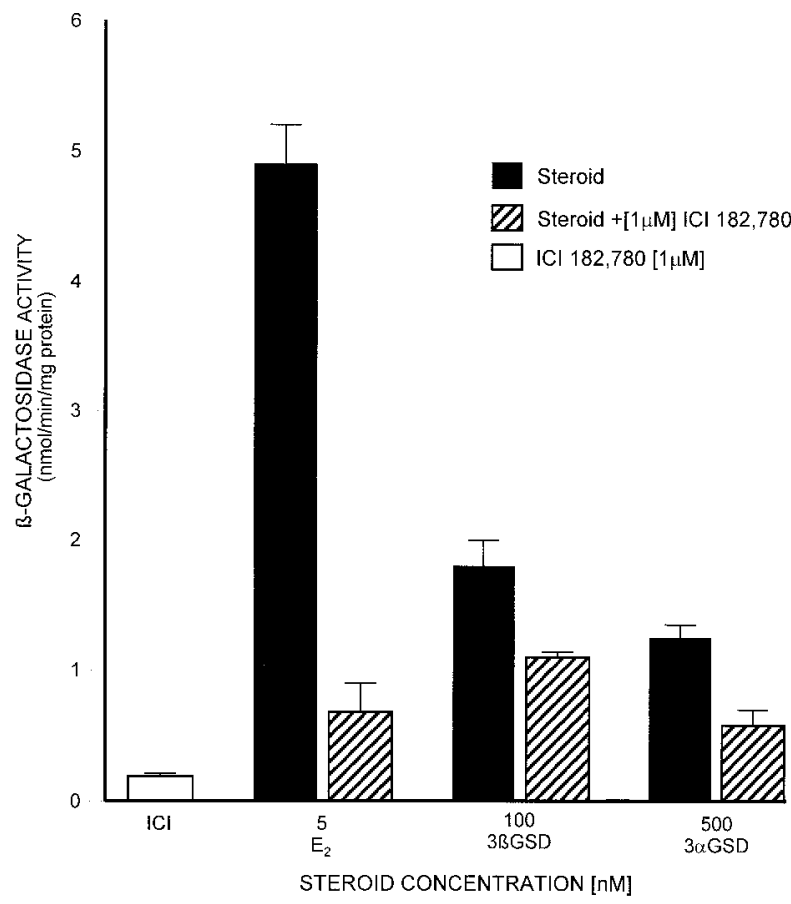

Figure 4 Effect of the pure anti-oestrogen ICl-182,780 (ICI) on the $\mathrm{hER} \alpha$-mediated $\beta$-galactosidase activity in the yeast expression system described in Fig. 3. Yeast cultures were exposed to $5 \mathrm{nM}$ $\mathrm{E}_{2}, 100 \mathrm{nM} 3 \beta \mathrm{GSD}$ and $500 \mathrm{nM} 3 \alpha \mathrm{GSD}$ in the absence or presence of $1 \mu \mathrm{M} \mathrm{ICl}$. Results are expressed as the $\beta$-galactosidase activity and each point represents the mean \pm S.D. of three experiments in triplicate. $\mathrm{E}_{2}$ and $\mathrm{ICl}$ alone were used as controls. The results show that $\mathrm{ICI}$ diminished the oestrogen-like effects of $3 \beta G S D$ and $3 \alpha G S D$, indicating that these effects are indeed hER $\alpha$-mediated.

rat pituitary cytosol sedimented at 7-9 $\mathrm{S}$ in linear sucrose gradients, whether induced by $\mathrm{E}_{2} \mathrm{~B}$ or by $3 \beta \mathrm{GSD}$ (Fig. 7). Addition of an excess of radioinert OR G 2058 completely abolished the PR labelling induced by the administration of $3 \beta \mathrm{GSD}$ (data not shown). These results demonstrated that $3 \beta$ GSD exhibits, in this model, oestrogenic effects similar to those observed after $\mathrm{E}_{2} \mathrm{~B}$ administration with a significantly lower potency.

\section{Discussion}

The results presented herein provide evidence that GSD, a widely used contraceptive synthetic progestin, exhibits limited oestrogen-like effects mediated by two of its A-ring reduced metabolites. Receptor binding studies demonstrated that GSD does not interact at all with ER, confirming and extending previous reports (Düstenberg et al. 1987, Wilde \& Balfour 1995). Interestingly however, the $3 \beta, 5 \alpha$ tetrahydro GSD derivative specifically binds to $\mathrm{ER}$, though with a significantly lower binding affinity than naturally occurring $\mathrm{E}_{2}$ (Fig. 2; Table 1). The $3 \alpha, 5 \alpha$ tetrahydro GSD derivative also interacts with ER, yet to

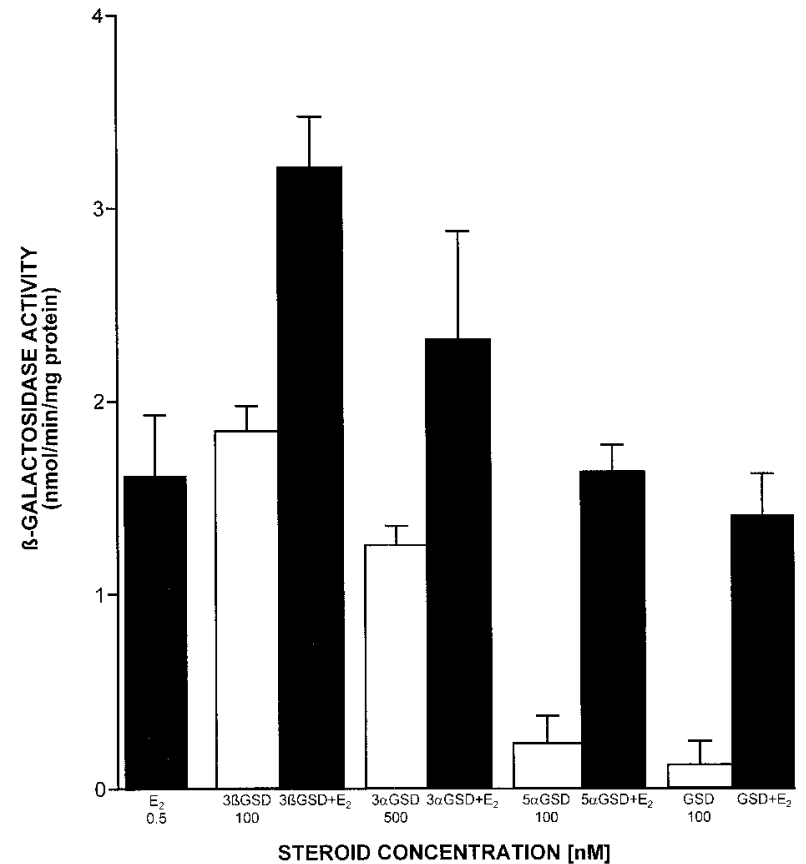

Figure 5 Effects of naturally occurring $E_{2}$ on the $\beta$-galactosidase activity stimulated by GSD and its A-ring reduced derivatives in the yeast expression system. Yeast were grown in the presence of $100 \mathrm{nM}$ GSD, $100 \mathrm{nM} 3 \beta \mathrm{GSD}$ and $500 \mathrm{nM} 3 \alpha \mathrm{GSD}$. $\mathrm{E}_{2}$ was added to incubations at $0.5 \mathrm{nM}$ concentration in ethanol. All determinations were performed at least in triplicate on three separate experiments. The results (mean \pm S.D.) demonstrate that GSD and its tetrahydro A-ring reduced derivatives, when incubated simultaneously with $E_{2}$, does not exhibit oestrogen synergistic effects. The data show an additive effect of $E_{2}$.

a significantly lesser extent than its $3 \beta$ isomeric alcohol (Fig. 2; Table 1). These results are similar but not identical to those reported for norethisterone (NET), another 19-nor synthetic contraceptive progestin; indeed, the $3 \beta, 5 \alpha$ and the $3 \alpha, 5 \alpha$ reduced NET metabolites specifically interact with ER (Chávez et al. 1985) though with a higher relative binding affinity than the corresponding GSD tetrahydro metabolites. The $5 \alpha$ dihydro derivative of GSD was unable to bind ER (Fig. 2), a finding that correlates with the previous observation that $5 \alpha$ dihydro NET is not recognised by ER (Chávez et al. 1985).

To assess whether the interaction of $3 \beta G S D$ and $3 \alpha \mathrm{GSD}$ with the ER results in genomic oestrogen-like effects, a transactivation yeast expression system was used. This system has proved to be a suitable model to evaluate hormone agonistic, synergistic and antagonistic activities (Lyttle et al. 1992). The results indicated that 3BGSD was able to induce hER $\alpha$-mediated $\beta$-galactosidase activity in a dose-response manner (Fig. 3) thus demonstrating a clear oestrogen-agonistic effect in this system. Indeed, the $3 \beta G S D$-induced transactivation of the $\beta$-galactosidase 


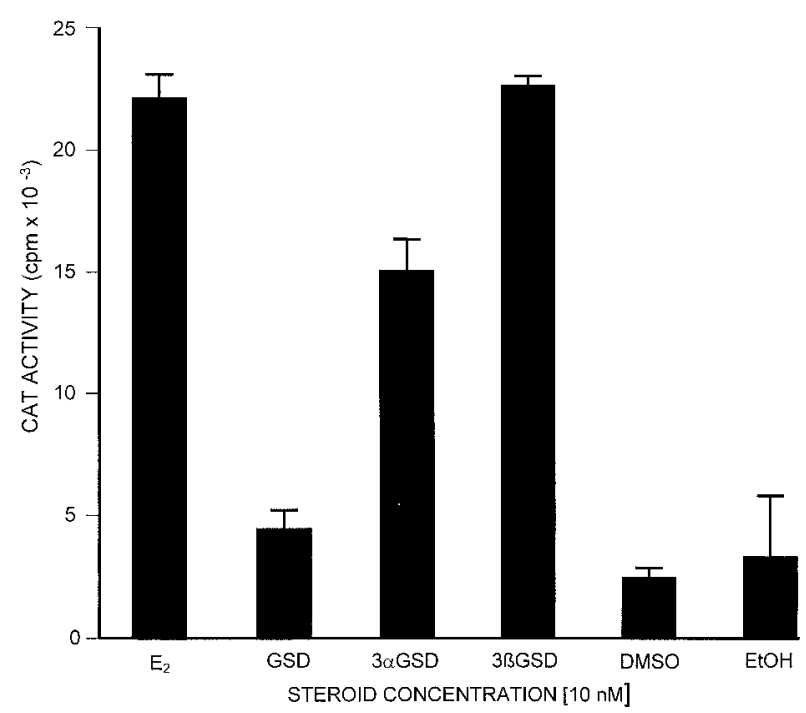

Figure 6 Induction of human ER $\alpha$-mediated transactivation of CAT by GSD and its A-ring reduced metabolites in a HeLa cell expression system. Cells were co-transfected with the expression vector for hER $\alpha$ (PCR 3-2-hER $\alpha$ ) and its cognate reporter

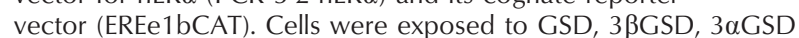
and $E_{2}$ at $10 \mathrm{nM}$ concentration. DMSO and $\mathrm{EtOH}$ were used as vehicles. Results are expressed as the CAT activity (c.p.m. $\times 10^{-3}$ ) and represent the mean \pm S.D. of triplicates. The results demonstrate that unmodified GSD was unable to induce hER $\alpha$-mediated CAT activity in this system, whereas 3 $\beta$ GSD exhibited oestrogen agonistic effects. $3 \alpha \mathrm{GSD}$ exhibited also oestrogen-like effects, though to a lesser extent than 3ßGSD.

gene was similar to that exhibited by $\mathrm{E}_{2}$ though with a significantly lower potency, an observation that is in line with their corresponding binding affinities for the ER. The $3 \alpha G S D$ isomer also induced hER $\alpha$-mediated $\beta$-galactosidase activity in a dose-dependent manner, indicating an oestrogen agonistic effect. The oestrogen-like potency of $3 \alpha \mathrm{GSD}$ was significantly lower than that of $3 \beta G S D$. The lack of oestrogen-like effects of unmodified GSD and $5 \alpha$ GSD correlates with their lack of binding to ER.

To provide additional support to the observation that oestrogenic effects of $3 \beta G S D$ and $3 \alpha \mathrm{GSD}$ are indeed hER $\alpha$-mediated, a study using ICI-182,780, a pure antioestrogen (Wakeling et al. 1991), was conducted. The results showed that ICI-182,780 significantly diminished

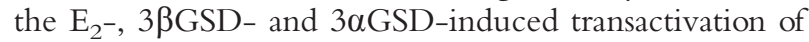
the $\beta$-galactosidase gene in the yeast expression system (Fig. 4), thus confirming that the oestrogenic actions of GSD tetrahydro derivatives are mediated through the $\mathrm{hER} \alpha$. Since GSD-containing oral contraceptive formulations are combined with ethynyl oestradiol, it was of interest to investigate whether GSD and/or its A-ring reduced metabolites may exert oestrogen synergistic effects. The results indicated that neither GSD nor its derivatives exhibited oestrogen synergism, rather an

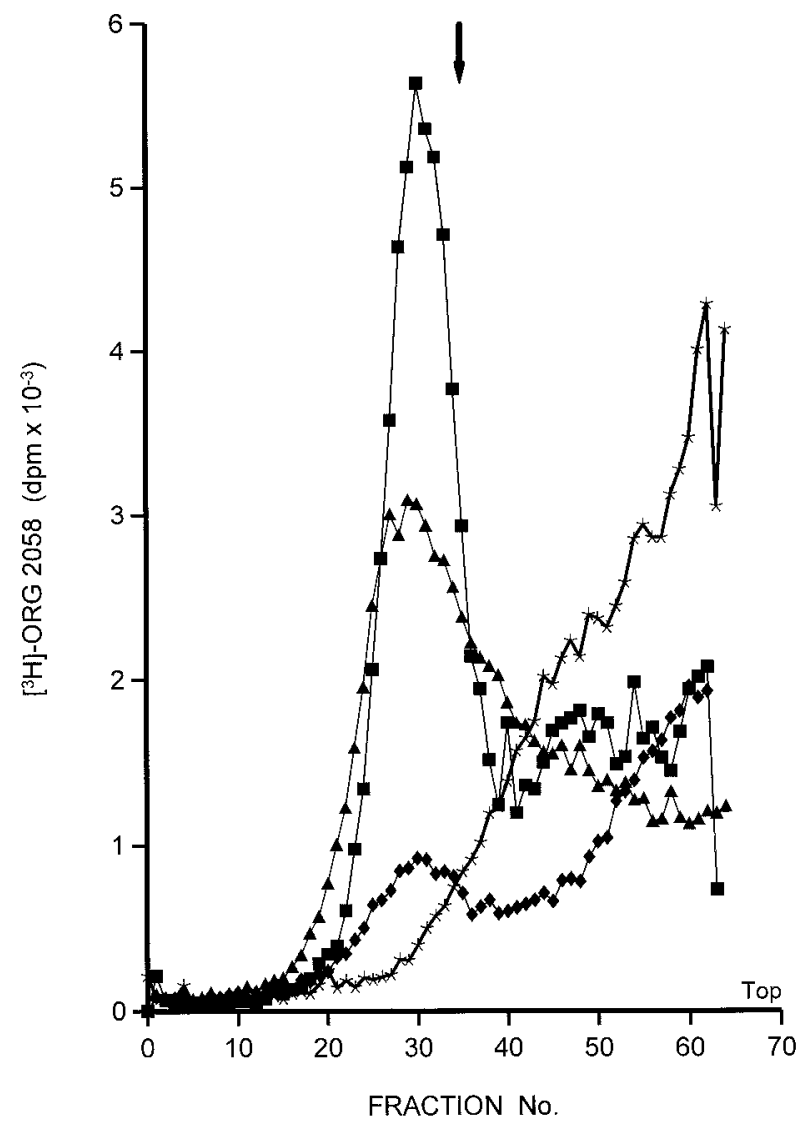

Figure 7 Induction of oestrogen-dependent PRs in the anterior pituitary of ovariectomised adult rats by $3 \beta$ GSD. PRs were assessed by a sucrose gradient labelling technique using $\left[{ }^{3} \mathrm{H}\right] \mathrm{ORG}$ 2058. BSA (arrow) was used as an external marker. Results are expressed as the sedimentation profile of PR (7-9 S) in cytosol pituitary preparations from animals treated for 6 consecutive days with different doses, $1000 \mu \mathrm{g}(\bullet)$ and $1500 \mu \mathrm{g}(\boldsymbol{\Delta})$ of $3 \beta G S D$. Animals treated with $5 \mu$ g oestradiol benzoate $\left(E_{2} B\right)$ /day for 6 days served as positive controls $(\boldsymbol{\square})$, whereas rats treated with vehicle alone $(*)$ were the negative controls. Administration of $E_{2} B$ fully restored the pituitary content of PR in castrated animals. $3 \beta G S D$ was effective in restoring oestrogen-dependent PR in a dose-dependent manner, though it was ineffective at the $500 \mu \mathrm{g} /$ day dose. Addition of an excess of radioinert ORG 2058 abolished the PR labelling induced by $3 \beta$ GSD (data not shown).

additive effect of GSD and its metabolites was observed when they were simultaneously incubated with $\mathrm{E}_{2}$ in the yeast expression system (Fig. 5).

To further evaluate the oestrogen-like potency of $3 \beta$ GSD and $3 \alpha \mathrm{GSD}$ in a mammalian expression system, $\mathrm{HeLa}$ cells co-transfected with the hER $\alpha$ and CAT vectors were used. The results demonstrated that unmodified GSD was unable to induce the $h E R \alpha$-mediated activation of CAT, thus indicating a lack of oestrogen agonistic effect. The $3 \beta, 5 \alpha$ reduced metabolite of GSD induced the transactivation of CAT in a similar manner to that of naturally occurring $E_{2}$ (Fig. 6). The $3 \alpha 5 \alpha$ reduced 
GSD derivative also was able to induce the hER $\alpha$ mediated CAT activation, though with a significantly lower potency than that exerted by $3 \beta G S D$. These results are similar to those obtained in the yeast expression system, indicating that both $3 \beta \mathrm{GSD}$ and $3 \alpha \mathrm{GSD}$ exert oestrogen actions mediated by the $\operatorname{hER} \alpha$, whereas their parent compound, GSD is completely devoid of these effects. Whether GSD and its derivatives also exert oestrogenic actions through the oestrogen receptor $\beta(\mathrm{ER} \beta)$ activation (Kuiper et al. 1996, Mosselman et al. 1996), can not be ascertained from these studies and deserve further investigation, particularly because of the relevant role that ER $\beta$ may play on the cardiovascular effects of oestrogens (Kuiper et al. 1997, Grohé et al. 1998, Giguère et al. 1998).

To investigate whether the receptor-mediated oestrogenic activity of $3 \beta \mathrm{GSD}$, demonstrated in both expression systems, may be expressed in an in vivo model, its ability to induce oestrogen-dependent PR in the anterior pituitary was studied in castrated female rats. The results demonstrated that $3 \beta G S D$ restored, in a dose-dependent manner, the rat pituitary content of $\mathrm{PR}$ in a similar fashion to that of $\mathrm{E}_{2} \mathrm{~B}$, though with a significantly lower potency (Fig. 7). This finding is similar to that previously reported for the $3 \beta, 5 \alpha$ derivative of NET (Vilchis et al. 1986); however, the oestrogen agonistic potency of $3 \beta, 5 \alpha \mathrm{GSD}$ was lower than that of the corresponding $3 \beta, 5 \alpha$ NET derivative, an observation that correlates with their relative binding affinities for the ER.

This study demonstrates that two GSD derivatives, $3 \beta G S D$ and $3 \alpha G S D$, possess weak oestrogenic activity and lack oestrogen synergistic actions. The weak oestrogenlike potency of the GSD metabolites, as assessed by their low RBA for the ER and the high concentration of $3 \beta G S D$ required to induce in vivo $\mathrm{PR}$ in the rat pituitary, does not appear to be related to some clinical effects attributed to GSD use. This observation is in line with the latest case-control studies and analyses which have found no difference in the VTD risk between users of oral contraceptives containing GSD or older 19-nor progestins, particularly when the data were controlled for age and duration of contraceptive use (Farmer \& Preston 1995, Spitzer et al. 1996, Farmer et al. 1997, WHO Scientific Group 1998, IFFS 1999).

The overall results provide a plausible explanation for those studies which have suggested that high concentrations of 19-nor progestins, including GSD, stimulate MCF-7 breast cancer cell growth by activating the ER (Van der Burg et al. 1992, Catherino et al. 1993, Kalkhoven et al. 1994, Schoonen et al. 1995). All in all, this study contributes to a better understanding of the mode of action of GSD.

\section{Acknowledgements}

This study has been supported by grants from the WHO Special Programme of Human Reproduction, Geneva,
Switzerland; the National Council of Science and Technology (CONACYT), Mexico City, Mexico, and the División de CBS, Universidad Autónoma Metropolitana-Iztapalapa. A J Cooney was supported by an Andrew P Melon Foundation grant. The authors would like to thank Drs C Richard Lyttle and Claudia Pérez, Wyeth Ayerst, Women's Health Research Institute, for the provision of the yeast model system. The assistance of Mr José Luis Ramírez is greatly appreciated.

\section{References}

Bardin CW 1983 The androgenic, antiandrogenic and synandrogenic actions of progestins. In Progesterone and Progestins, pp 135-147. Eds CW Bardin, E Milgröm \& P Mauvais-Jarvis. New York: Raven.

Bowers A, Ringold HJ \& Derot E 1958 Steroids CL. 19-nordihydrotestosterone derivatives. Journal of the American Chemical Society 80 6115-6121.

Bradford MM 1976 A rapid and sensitive method for the quantitation of microgram quantities of protein utilizing the principle of protein-dye binding. Analytical Biochemistry 72 248-254.

Brown HC \& Krifhnamurthy S 1972 Lithium tri-sec-butyl borohydride. A new reagent for the reduction of cyclic and bicyclic ketones with superstereo selectivity. Journal of the American Chemical Society 94 7159-7161.

Catherino WH, Jeng MH \& Jordan VC 1993 Norgestrel and gestodene stimulate breast cancer cell growth through an oestrogen receptor mediated mechanism. British Journal of Cancer 67 945-952.

Chávez BA, Vilchis F, Pérez AE, García GA, Grillasca I \& PérezPalacios G 1985 Stereospecificity of the intracellular binding of norethisterone and its A-ring reduced metabolites. Journal of Steroid Biochemistry 22 121-126.

Cheng YC \& Prusoff WH 1973 Relationship between the inhibition constant $\left(\mathrm{K}_{\mathrm{i}}\right)$ and the concentration oh inhibitor which causes 50 percent inhibition $\left(\mathrm{IC}_{50}\right)$ of an enzymatic reaction. Biochemistry and Pharmacology 22 3099-3108.

Cooney AJ, Tsai SY, O’Malley BW \& Tsai M-J 1992 The chicken ovalbumin upstream promoter transcription factor dimers bind to different GGTCA response elements allowing it to repress hormonal induction of vitamin $\mathrm{D}$ receptor, thyroid receptor, and retinoic acid receptor. Molecular Cell Biology $124153-4163$.

Cooney AJ, Leng X, Tsai SY, O’Malley BW \& Tsai M-J 1993 Multiple mechanisms of chicken ovalbumin upstream promoter transcription factor-dependent repression of vitamin D receptor, thyroid receptor, and retinoic acid receptor transactivation. Journal of Biological Chemistry 268 4152-4160.

Düstenberg B, Tack JW, Jrause W \& Humpel M 1987 Pharmacokinetics and biotransformation of gestodene in man. In Gestodene. Development of a New Gestodene-containing Low Dose Oral Contraceptive, pp 35-44. Ed M Elstein. Carnforth, Lancs, UK: Parthenon.

Farmer R \& Preston T 1995 The risk of venous thromboembolism associated with low oestrogen dose oral contraceptives. Journal of Obstetrics and Gynecology 15 195-200.

Farmer R, Lawrenson R, Thompson C, Kennedy J \& Hambleton R 1997 Population based study of risk of venous thromboembolism associated with various oral contraceptives. Lancet 349 83-88.

Fotherby K \& Caldwell ADS 1994 New progestogens in oral contraception. Contraception 49 1-132.

Giguère V, Tremblay A \& Tremblay GB 1998 Estrogen receptor $\beta$ : re-evaluation of estrogen and antiestrogen signaling. Steroids $\mathbf{6 3}$ 335-339.

Grohé C, Kahlert S, Löbbert K \& Vetter H 1998 Expression of oestrogen receptor $\alpha$ and $\beta$ in rat heart: role of local oestrogen synthesis. Journal of Endocrinology 156 R1-R7. 
Helmrich SP, Rosenberg L, Kaufman DW, Strom B \& Shapiro S 1987 Venous thromboembolism in relation to oral contraceptive use. Obstetrics and Gynecology 69 91-95.

IFFS 1999 Consensus conference on combination oral contraceptives and cardiovascular disease 1999. Fertility and Sterility 71 (Suppl 6) 1S-6S.

Inman WHW \& Vessey MP 1968 Investigation of deaths from pulmonary, coronary, and cerebral thrombosis and embolism in women of child-bearing age. British Medical Journal 2 193-199.

Jick H, Jick SS, Gurewich V, Myers MW \& Vasilakis C 1995 Risk of idiopathic cardiovascular death and nonfatal venous thromboembolism in women using oral contraceptives with differing progestagen components. Lancet 346 1589-1593.

Kalkhoven E, Kwakkenbos-Isbrüker L, de Laat SW, van der Saag PT \& van der Burg B 1994 Synthetic progestins induce proliferation of breast tumor cell lines via the progesterone or estrogen receptor. Molecular and Cell Endocrinology 102 45-52.

Kuhl H 1996 Comparative pharmacology of newer progestogens. Drugs 51 188-215.

Kuiper GGJM, Enmark E, Pelto-Huikko M, Nilsson F \& Gustafsson J-Å 1996 Cloning of a novel estrogen receptor expressed in rat prostate and ovary. PNAS 93 5924-5930.

Kuiper GGJM, Carlsson B, Grandien K, Enmark E, Häggblad J, Nilsson S \& Gustafsson J-Å 1997 Comparison of the ligand binding specificity and transcript tissue distribution of estrogen receptors $\alpha$ and $\beta$. Endocrinology 138 863-870.

Larrea F, Vilchis F, Chávez B, Pérez AE, Garza-Flores J \& PérezPalacios G 1987 The metabolism of 19-nor contraceptive progestins modulates their biological activity at the neuroendocrine level. Journal of Steroid Biochemistry 27 657-663.

Lemus AE, Vilchis F, Damsky B, Chávez BA, García GA, Grillasca I \& Pérez-Palacios G 1992 Mechanism of action of levonorgestrel: in vitro metabolism and specific interactions with steroid receptors in target organs. Journal of Steroid Biochemistry and Molecular Biology 41 881-890.

Lemus AE, Enríquez J, García GA, Grillasca I \& Pérez-Palacios G $19975 \alpha$-Reduction of norethisterone enhances its binding affinity for androgen receptor but diminishes its androgenic potency. Journal of Steroid Biochemistry and Molecular Biology 60 121-129.

Lewis MA, Heinemann LAJ, MacRae KD, Bruppacher R \& Spitzer WO 1996 The increased risk of venous thromboembolism and the use of third generation progestagens: role of bias in observational research. Contraception 54 5-13.

Lyttle CR, Damián-Matsumura P, Juul H \& Butt T 1992 Human estrogen receptor regulation in a yeast model system and studies on receptor agonists and antagonists. Journal of Steroid Biochemistry and Molecular Biology 42 677-685.

Moralí G, Lemus AE, Oropeza MV, García GA \& Pérez-Palacios G 1990 Induction of male sexual behavior by norethisterone: role of its A-ring reduced metabolites. Pharmacology Biochemistry and Behavior 37 477-484.

Mosselmman S, Polmman J \& Dijkema R 1996 ER $\beta$ : identification and characterization of a novel human estrogen receptor. FEBS Letters 392 49-53.

Pérez-Palacios G, Cerbón MA, Pasapera AM, Castro JI, Enríquez J, Vilchis F, García GA, Moralí G \& Lemus AE 1992 Mechanisms of hormonal and antihormonal action of contraceptive progestins at the molecular level. Journal of Steroid Biochemistry and Molecular Biology 41 479-485.

Reel JR, Humphrey RR, Shih Y, Windsor BL, Sakovsky R, Creger PL \& Edgren RA 1979 Competitive progesterone antagonists: receptor binding and biological activity of testosterone and 19-nortestosterone derivatives. Fertility and Sterility 31 552-561.
Schoonen WGEJ, Joosten JWH \& Kloosterboer HJ 1995 Effects of two classes of progestagens, pregnane and 19-nortestosterone derivatives, on cell growth of human breast tumor cells: I. MCF-7 cell lines. Journal of Steroid Biochemistry and Molecular Biology $\mathbf{5 5}$ $423-437$.

Seed B \& Sheen JY 1998 A simple phase-extraction assay for chloramphenicol acyltransferase activity. Gene 67 271-277.

Sherman F, Fik GR \& Hicks JB 1982 Methods in Yeast Genetics: a Laboratory Manual. New York: Cold Spring Harbor Laboratory Press.

Spitzer WO, Lewis MA, Heinemann LAJ, Thorogood M \& MacRae 1996 Third generation oral contraceptives and risk of venous thromboembolic disorders: an international case-control study. British Medical Journal 312 83-88.

Still WC, Kahan M \& Mitra A 1978 Rapid chromatographic technique for preparative separation with moderate resolution. Journal of Organic Chemistry 43 2923-2925.

Van der Burg B, Kalkhoven E, Isbrücker L \& de Laat SW 1992 Effects of progestins on the proliferation of estrogen-dependent human breast tumor cells under growth factor-defined conditions. Journal of Steroid Biochemistry and Molecular Biology 42 457-465.

Vandenbroucke JP, Koster T, Briët E, Reitsma PH, Bertina RM \& Rosendaal FR 1994 Increased risk of venous thrombosis in oral contraceptive users who are carriers of factor V Leiden mutation. Lancet 344 1453-1457.

Vessey M, Mant D, Smith A \& Yeates D 1986 Oral contraceptives and venous thromboembolism: findings in a large prospective study. British Medical Journal 292526.

Vilchis F, Chávez B, Pérez AE, García G, Angeles A \& Pérez-Palacios G 1986 Evidence that a non aromatizable metabolite of norethisterone induces estrogen-dependent pituitary progestin receptors. Journal of Steroid Biochemistry 24 525-531.

Wakeling AE, Dukes M \& Bowler J 1991 A potent specific pure antiestrogen with clinical potential. Cancer Research 51 3867-3873.

WHO 1989 WHO Collaborative Study. Cardiovascular disease and use of oral contraceptives. Bulletin of the World Health Organization 67 417-423.

WHO 1995a WHO Collaborative Study of Cardiovascular Disease and Steroid Hormone Contraception. Venous thromboembolic disease and combined oral contraceptives: results of international multicentre case-control study. Lancet 346 1575-1582.

WHO 1995 W WHO Collaborative Study of Cardiovascular Disease and Steroid Hormone Contraception. Effect of different progestagens in low oestrogen oral contraceptives on venous thromboembolic disease. Lancet 346 1582-1588.

WHO Scientific Group 1998 Cardiovascular disease and steroid hormone contraception. WHO Technical Report Series 877 41-51.

Wilde MI \& Balfour AJ 1995 Gestodene: a review of its pharmacology, efficacy and tolerability in combined contraceptive preparations. Drugs 50 364-395.

Winkler UH 1998 Effects on hemostatic variables of desogestrel- and gestodene-containing oral contraceptives in comparison with levonorgestrel-containing oral contraceptives: a review. American Journal of Obstetrics and Gynecology 179 S51-S61.

Received 25 October 1999

Revised manuscript received 31 January 2000

Accepted 10 February 2000 